\title{
Aged garlic extract and S-allylcysteine prevent apoptotic cell death in a chemical hypoxia model
}

\author{
Marisol Orozco-lbarra', Jorge Muñoz-Sánchez², Martín E. Zavala-Medina², Benjamín Pineda², \\ Roxana Magaña-Maldonado ${ }^{3}$, Edgar Vázquez-Contreras ${ }^{4}$, Perla D. Maldonado², José Pedraza-Chaverri ${ }^{5}$ \\ and María Elena Chánez-Cárdenas ${ }^{2 *}$
}

\begin{abstract}
Background: Aged garlic extract (AGE) and its main constituent S-allylcysteine (SAC) are natural antioxidants with protective effects against cerebral ischemia or cancer, events that involve hypoxia stress. Cobalt chloride $\left(\mathrm{CoCl}_{2}\right)$ has been used to mimic hypoxic conditions through the stabilization of the a subunit of hypoxia inducible factor (HIF-1a) and up-regulation of HIF-1a-dependent genes as well as activation of hypoxic conditions such as reactive oxygen species (ROS) generation, loss of mitochondrial membrane potential and apoptosis. The present study was designed to assess the effect of AGE and SAC on the $\mathrm{CoCl}_{2}$-chemical hypoxia model in PC12 cells.

Results: We found that $\mathrm{CoCl}_{2}$ induced the stabilization of HIF-1a and its nuclear localization. $\mathrm{CoCl}_{2}$ produced ROS and apoptotic cell death that depended on hypoxia extent. The treatment with AGE and SAC decreased ROS and protected against $\mathrm{CoCl}_{2}$-induced apoptotic cell death which depended on the $\mathrm{CoCl}_{2}$ concentration and incubation time. SAC or AGE decreased the number of cells in the early and late stages of apoptosis. Interestingly, this protective effect was associated with attenuation in HIF-1 a stabilization, activity not previously reported for AGE and SAC.
\end{abstract}

Conclusions: Obtained results show that AGE and SAC decreased apoptotic $\mathrm{CoCl}_{2}$-induced cell death. This protection occurs by affecting the activity of HIF-1 $a$ and supports the use of these natural compounds as a therapeutic alternative for hypoxic conditions.

Keywords: Aged garlic extract, Chemical hypoxia, Cobalt chloride, Hypoxia-inducible factor 1, PC12 cells, S-allylcysteine

\section{Background}

Hypoxia is a component of physiological events and multiple pathophysiological conditions, including neonatal hypoxia, cerebral ischemia, peripheral vascular disease, myocardial infarction, coronary heart disease and cancer $[1,2]$. Hypoxic stress to cells alters gene expression regulation, leading to subsequent recovery processes or cell death. Hypoxia-inducible factor 1 (HIF-1) is the master

\footnotetext{
*Correspondence: echanezc@gmail.com; echanez@bq.unam.mx ${ }^{2}$ Laboratorio de Patología Vascular Cerebral, Instituto Nacional de Neurología y Neurocirugía Manuel Velasco Suárez, Av. Insurgentes Sur \# 3877, Colonia La Fama, Delegación Tlalpan, 14269 Mexico D.F., Mexico Full list of author information is available at the end of the article
}

regulator of oxygen homeostasis, and adaptive cellular responses to reduced oxygen availability are primarily regulated by the stabilization/degradation ratio of the $\alpha$ subunit of the transcription factor HIF-1 [3-5].

Cobalt chloride $\left(\mathrm{CoCl}_{2}\right)$ has been widely used to imitate hypoxic conditions both in vivo $[6,7]$ and in vitro $[8,9] . \mathrm{CoCl}_{2}$ mimics several aspects of the hypoxic response, such as increasing and stabilizing HIF- $1 \alpha$ protein through inhibition of Prolyl Hydroxylases (PHDs) activity and producing reactive oxygen species (ROS), which leads to cell damage, decreased cell viability and apoptosis [9-11]. Previous studies have clearly shown that $\mathrm{CoCl}_{2}$-induced cell damage is associated with an increase in ROS that subsequently induces apoptosis. 
Apoptotic morphology, DNA fragmentation, activation of caspases -3 and -9 , loss of mitochondrial membrane potential, cytochrome $\mathrm{c}$ release, upregulation of Bax and down-regulation of $\mathrm{Bcl} 2,[8,9,12-16]$ as well as p38MAPK activation [13] has been observed as result of $\mathrm{CoCl}_{2}$ induced damage.

The current study assessed the mechanism of action and protective effect of two antioxidant garlic derivatives, aged garlic extract (AGE) and S-allylcysteine (SAC), on hypoxia-induced damage.

AGE is the result of prolonged (20 months) garlic extraction in $20 \%$ ethanol. This aging process converts unstable and odorous compounds into odorless and stable forms $[17,18]$. The most abundant organosulfur compound in AGE is SAC ( $0.6 \mathrm{mg} / \mathrm{g}$ product); however, other AGE compounds, such as S-allylmercaptocysteine, alliin, N $\alpha$-(1-deoxy-D-fructos-1-yl)-Larginine and tetrahydro-beta-carbolines, have been shown to inhibit oxidizing events and to scavenge free radicals and oxidant species such as hydroxyl radicals $\left({ }^{\circ} \mathrm{OH}\right)$, superoxide anions $\left(\mathrm{O}_{2}{ }^{*}\right)$ and hydrogen peroxide $\left(\mathrm{H}_{2} \mathrm{O}_{2}\right)$. The evidence shows that AGE can ameliorate the oxidative damage implicated in aging and a variety of diseases, including cardiovascular alterations, cancer, stroke, Alzheimer's disease, and other age-related degenerative conditions (reviewed in [19]). The protective effect of AGE in different models has been associated with its antioxidant properties [20-22], reviewed in [23].

SAC is the best characterized AGE compound. It is formed by $\gamma$-glutamyl-S-allylcysteine catabolism and has been used to standardize commercial AGE [24]. Previous studies have shown that SAC scavenges $\mathrm{O}_{2}{ }^{--}$[25], $\mathrm{H}_{2} \mathrm{O}_{2},{ }^{\circ} \mathrm{OH}$, peroxynitrite anions, hypochlorous acid, singlet oxygen and peroxyl radicals [25, 26]. It also prevents $\mathrm{H}_{2} \mathrm{O}_{2}$-induced peroxidation and $\mathrm{H}_{2} \mathrm{O}_{2}$-induced activation of NFKB. SAC administration increases glutathione levels as well as catalase and glutathione peroxidase activities [19].

$\mathrm{CoCl}_{2}$-treated $\mathrm{PC} 12$ cells have been used to study the mechanisms underlying cell death due to hypoxia/ ischemia conditions because they are particularly sensitive to hypoxic changes and reproduce apoptotic cell death $[8,9,12-14]$. We investigated the effect of AGE and SAC on cell death to determine the mechanisms behind $\mathrm{CoCl}_{2}$-induced injuries in PC12 cells. Our results showed that the protective effect of SAC and AGE was due to the preservation of cell viability and a decrease in cell death, particularly $\mathrm{CoCl}_{2}$-induced apoptosis. Our observations suggest that this increased cell survival occurs through the attenuation of HIF- $1 \alpha$ stabilization and binding activity via the direct antioxidant effects of AGE and SAC.

\section{Results \\ $\mathrm{CoCl}_{2}$ affects cell viability in a concentration- and time-dependent manner}

Concentration- and time-dependent changes in MTT reduction were used to assess $\mathrm{CoCl}_{2}$ induced effects. Cells were incubated for 24 or $48 \mathrm{~h}$ at increasing concentrations of $\mathrm{CoCl}_{2}$. Concentration- and time-dependent decreases in cell viability were observed. A significant reduction was observed at $0.5 \mathrm{mM} \mathrm{CoCl}$ for both time periods tested (Fig. 1a). The lowest cell viability percentage was observed after 24-h incubation with $1.0 \mathrm{mM} \mathrm{CoCl}_{2}$ (50\%). At $48 \mathrm{~h}$, a $50 \%$ MTT reduction was observed after exposure between 0.4 and $0.6 \mathrm{mM} \mathrm{CoCl}_{2}$. Representative bright field micrographs of cells at 0 (vehicle), 0.5 and $1.0 \mathrm{mM}$ $\mathrm{CoCl}_{2}$ at 24 or $48 \mathrm{~h}$ are shown in Fig. 1b. Time-dependent cell shrinkage and irregular shapes were found in cells treated with 0.5 and $1.0 \mathrm{mM} \mathrm{CoCl}_{2}$. These data are consistent with the MTT reduction results.

\section{$\mathrm{CoCl}_{2}$ stabilizes HIF-1a and increases binding to hypoxia response elements (HRE) sequence}

The binding of stabilized HIF- $1 \alpha$ was determined using ELISA (Fig. 2). The binding of nuclear HIF-1 $\alpha$ to HRE sequence was increased by approximately 6- and 4-fold after a 24-h exposure to 0.5 and $1.0 \mathrm{mM} \mathrm{CoCl}_{2}$, respectively. $\mathrm{CoCl}_{2}$ incubation for $48 \mathrm{~h}$ induced further increases of 19- and 35-fold after exposure to 0.5 and $1.0 \mathrm{mM} \mathrm{CoCl}$, respectively. No signal was detected in cells incubated with $0.15 \mathrm{mM} \mathrm{CoCl}_{2}$ for $30 \mathrm{~min}$ or $1 \mathrm{~h}$ (data not shown). Based on these results and the MTT data (Fig. 1), we used exposure to 0.5 and $1.0 \mathrm{mM} \mathrm{CoCl}_{2}$ for 24 or $48 \mathrm{~h}$ for subsequent experiments.

\section{SAC and AGE prevent $\mathrm{CoCl}_{2}$-induced toxicity}

To determine the effect of SAC and AGE on $\mathrm{CoCl}_{2}$ induced toxicity, cells were co-incubated with SAC or AGE and $\mathrm{CoCl}_{2}$ for 24 or $48 \mathrm{~h}$ as stated in the experimental design. The level of MTT reduction was determined. Concentrations of 5 or $10 \mathrm{mM} \mathrm{SAC}$ and 0.5 or $1.0 \%$ AGE were chosen based on previous in vitro reports (SAC: [27, 28]; AGE: [29, 30]) and toxicity experiments using SAC (0-20 mM) or AGE (0-1 \%) for 24 and $48 \mathrm{~h}$ (data not shown). After $24 \mathrm{~h}, 0.5 \mathrm{mM} \mathrm{CoCl}$ reduced cell viability to $60 \%$, and co-incubation with SAC (5 or $10 \mathrm{mM}$ ) completely restored cell viability (Fig. 3a). Similar results were obtained with AGE, including a partial increase in cell viability after treatment with $0.5 \% \mathrm{AGE}$ and almost complete prevention with $1.0 \%$ AGE after cells were incubated with $0.5 \mathrm{mM} \mathrm{CoCl}_{2}$ (Fig. 3b). Neither SAC (Fig. 3a) nor AGE (Fig. 3b) exhibited a significant protective effect on the toxicity induced by $1.0 \mathrm{mM} \mathrm{CoCl}_{2}$. The toxicity induced by $0.5 \mathrm{mM}$ or $1.0 \mathrm{mM} \mathrm{CoCl}$ for $48 \mathrm{~h}$ was clearly prevented by co-incubation with either SAC (Fig. 3c) or 


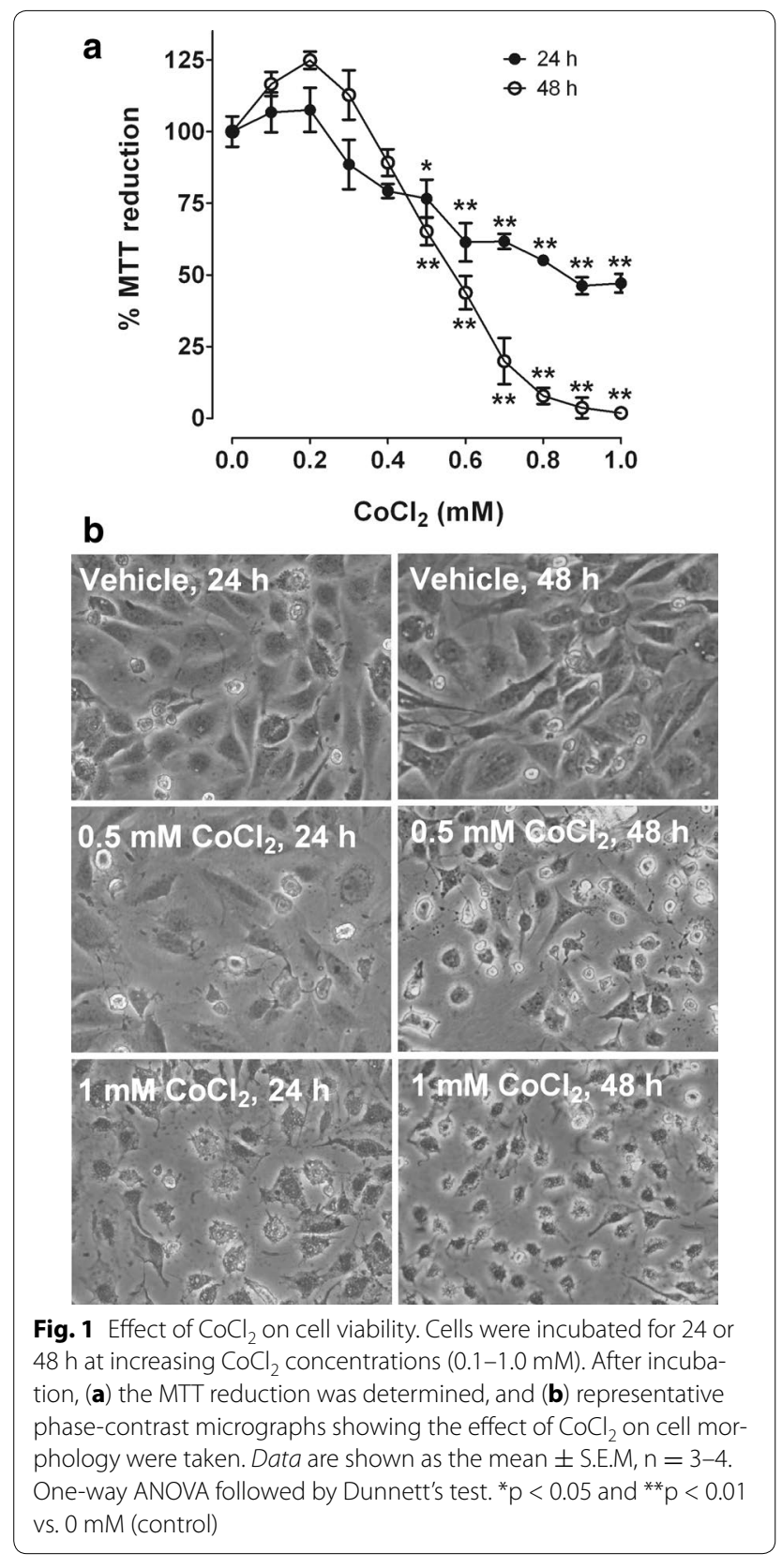

AGE (Fig. 3d). Based on these results, subsequent experiments were conducted using $10 \mathrm{mM} \mathrm{SAC}$ and $1 \% \mathrm{AGE}$ for $48 \mathrm{~h}$.

\section{SAC and AGE prevent cell death induced by $\mathrm{CoCl}_{2}$}

To further investigate the effect of SAC and AGE on $\mathrm{CoCl}_{2}$-induced cell death, we monitored the cell cycle profile using fluorescence-activated cell sorting (FACS) analysis (Fig. 4). The fraction of cells in the Sub- $G_{0}$ phase increased from 3 to $22 \%$ after exposure to $0.5 \mathrm{mM}$ $\mathrm{CoCl}_{2}$ for $48 \mathrm{~h}$ and $39 \%$ after exposure to $1.0 \mathrm{mM} \mathrm{CoCl}_{2}$

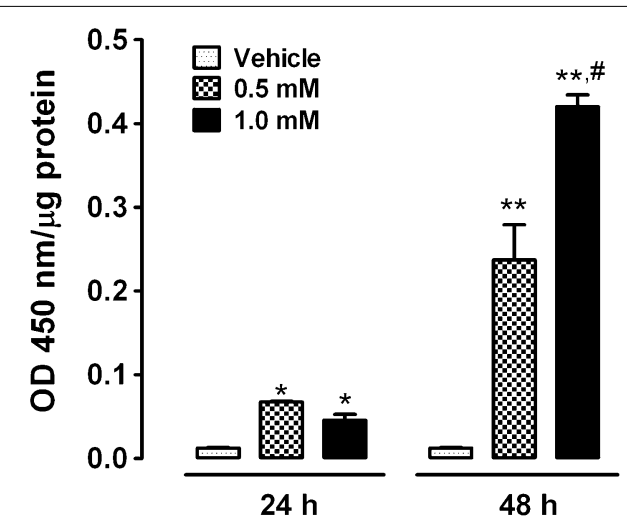

Fig. 2 Effect of $\mathrm{COCl}_{2}$ on $\mathrm{HIF}-1$ a stabilization and binding activity. Cells were incubated for 24 or $48 \mathrm{~h}$ with 0.5 or $1.0 \mathrm{mM} \mathrm{CoCl}_{2}$. Binding of nuclear HIF-1a to HRE sequences was determined using an ELISA. Data are shown as the mean \pm S.E.M, $n=3$. Two-way ANOVA followed by Bonferroni comparisons. ${ }^{*} p<0.05$ and ${ }^{* *} p<0.001$ vs. vehicle at the same time point, ${ }^{\#} \mathrm{p}<0.001$ vs. $0.5 \mathrm{mM} \mathrm{CoCl}_{2}$ at the same time point

(compared to vehicle). Both SAC and AGE prevented this increase. Co-incubation with SAC and AGE reduced the $0.5 \mathrm{mM} \mathrm{CoCl}_{2}$-induced cell death to 5 and $8 \%$, respectively. Cells exposed to $1.0 \mathrm{mM} \mathrm{CoCl}_{2}$ and SAC or AGE showed a decrease in cell death from 39 to 17 and $20 \%$, respectively.

\section{SAC and AGE prevent $\mathrm{CoCl}_{2}$-induced apoptosis}

The Annexin V/7-AAD staining in Fig. 5 shows the effect of $\mathrm{CoCl}_{2}$ and SAC or AGE on cell death. Representative figures are shown in Fig. 5 (a-f). The analysis of six independent experiments is shown in Fig. 5 $(g-j)$. In agreement with the MTT reduction and Sub- $\mathrm{G}_{0}$ peak results, $\mathrm{SAC}$ and $\mathrm{AGE}$ prevented $\mathrm{CoCl}_{2}$ induced cell death. The known apoptosis inducer in PC12 cells staurosporine ( $200 \mathrm{nM})$ was used as a positive control (Additional file 1: Figure S1). The percentage of live cells at $0.5 \mathrm{mM} \mathrm{CoCl}{ }_{2}$ was $22 \%$, and co-incubation with SAC or AGE increased cell viability to $50 \%$. Co-incubation of cells with $1.0 \mathrm{mM} \mathrm{CoCl}_{2}$ and SAC or AGE prevented cell death and increased the percentage of live cells from 8 to 30 and $40 \%$, respectively (Fig. 5h). Single 7-AAD + cells were less than $10 \%$ for both $\mathrm{CoCl}_{2}$ concentrations (Fig. 5g). Early apoptotic cells (single Annexin + ) increased from $15 \%$ to approximately $50 \%$ after exposure to $0.5 \mathrm{mM} \mathrm{CoCl}_{2}$. This increase was prevented by co-incubation with SAC (to $20 \%$ ) or AGE (to $25 \%$ ) (Fig. 5i). In addition, $1.0 \mathrm{mM} \mathrm{CoCl}_{2}$ induced an increase in Annexin +/7AAD + cells from $15 \%$ to approximately $60 \%$, and both SAC and AGE attenuated this effect to 35 and $18 \%$, respectively (Fig. 5 j). 


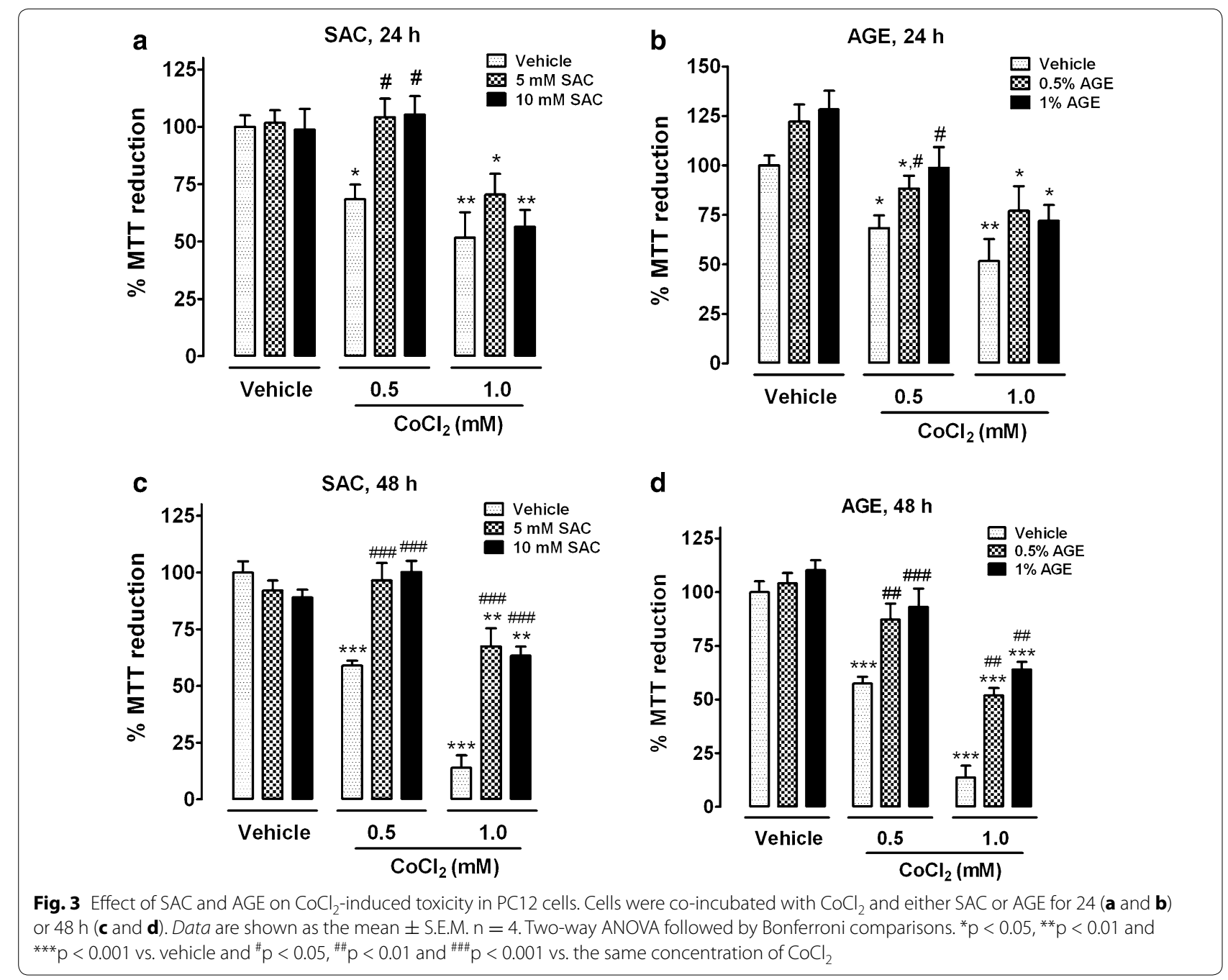

SAC and AGE decrease $\mathrm{CoCl}_{2}$-induced ROS generation In addition to the increase in HIF- $1 \alpha$ protein stabilization, $\mathrm{CoCl}_{2}$ mimics other hypoxia responses, including ROS generation. Figure 6a shows the increase in the 2', 7 'dichlorofluorescein (DCF)-derived fluorescence of cells exposed for $1 \mathrm{~h}$ to 0.5 and $1.0 \mathrm{mM} \mathrm{CoCl} \mathrm{C}_{2}$ (vehicle bars). Co-incubation with $10 \mathrm{mM} \mathrm{SAC}$ or $1 \%$ AGE decreased the ROS generated from exposure to both $\mathrm{CoCl}_{2}$ concentrations.

\section{SAC and AGE decrease $\mathrm{CoCl}_{2}$-induced HIF-1a stabilization and binding to $\mathrm{HRE}$ sequence}

The effect of SAC and AGE on nuclear HIF- $1 \alpha$ stabilization and binding to HRE sequences was tested using an ELISA. A significant increase in the HIF- $1 \alpha$ signal was observed at 0.5 and $1.0 \mathrm{mM} \mathrm{CoCl} 2$ (20- and 35-fold, respectively), and $\mathrm{SAC}$ and $\mathrm{AGE}$ prevented the increase in HIF- $1 \alpha$. Exposure to $0.5 \mathrm{mM} \mathrm{CoCl}_{2}$ decreased HIF- $1 \alpha$ binding activity from 20 -fold to 3 -fold with $\mathrm{SAC}$ and 7-fold with AGE. At $1.0 \mathrm{mM} \mathrm{CoCl} 2$, HIF- $1 \alpha$ activity decreased from 35-fold to 13-fold and 19-fold with SAC or AGE, respectively (Fig. 6b).

\section{Discussion}

The cellular injury caused by hypoxia is involved in pathological events, such as cerebral ischemia, neonatal hypoxia and cancer. Thus, it is relevant to explore the mechanisms underlying the potential protective effects of compounds through hypoxia models.

The chemical hypoxia model induced by $\mathrm{CoCl}_{2}$ exposure in PC12 cells is a useful in vitro model to elucidate the mechanisms behind hypoxia damage and test novel compounds because it reproduces many hypoxic conditions, including ROS generation, mitochondrial membrane potential changes, induction of apoptosis [12-16] and HIF- $1 \alpha$-regulated transcriptional responses $[8,9]$. In this study, we observed that exposure to 0.5 and $1.0 \mathrm{mM}$ $\mathrm{CoCl}_{2}$ for 24 or $48 \mathrm{~h}$ induced the stabilization and 


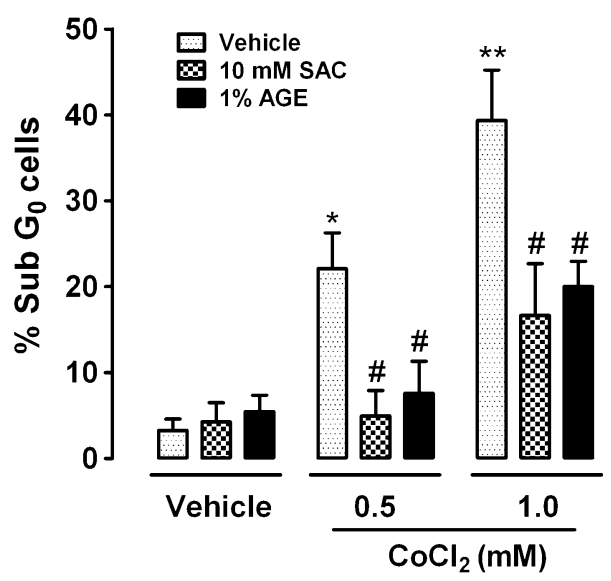

Fig. 4 Effect of SAC or AGE co-incubation with $\mathrm{CoCl}_{2}$ on the $\mathrm{Sub}-\mathrm{G}_{0}$ peak. Cells were co-incubated with $10 \mathrm{mM} \mathrm{SAC}$ or $1 \%$ AGE and 0.5 or $1.0 \mathrm{mM} \mathrm{CoCl}_{2}$ for 48 h. Sub- $\mathrm{G}_{0}$ data were obtained using flow cytometry with cells incubated with PI. Data are shown as the mean \pm S.E.M. $n=4-5$. Two-way ANOVA followed by Bonferroni comparisons. ${ }^{*} p<0.01$ and ${ }^{* *} p<0.001$ vs. control cells (vehicle), $\# p<0.01$ vs. the same concentration of $\mathrm{CoCl}_{2}$

translocation of HIF- $1 \alpha$ to the nucleus, confirming that $\mathrm{CoCl}_{2}$ can mimic hypoxia in PC12 cells $[8,15]$.

This study was designed to determine the effect of two garlic-derived antioxidants, AGE and SAC, in PC12 cells subjected to chemical hypoxia induced by $\mathrm{CoCl}_{2}$. We observed that co-incubation of AGE or SAC with $\mathrm{CoCl}_{2}$ exerted a protective effect against the $\mathrm{CoCl}_{2}$-induced cell viability decrease. In the case of $1.0 \mathrm{mM} \mathrm{CoCl}_{2}$, it was clearly evident only after longer periods of exposure (48 h). Cell function was almost completely recovered for SAC or AGE co-incubation with $0.5 \mathrm{mM} \mathrm{CoCl}_{2}$ at both tested times. In contrast, $1.0 \mathrm{mM} \mathrm{CoCl}_{2}$ had a pronounced toxicity effect that results in an apparent lack of protection at both SAC and AGE concentrations tested at $24 \mathrm{~h}$ (Fig. 3a, b). Interestingly, a protective effect exerted by SAC and AGE was observed at $48 \mathrm{~h}$, with a significant recovery of the cell viability at $1.0 \mathrm{mM} \mathrm{CoCl}_{2}$ (Fig. 3c, d). Noteworthy, about the same percentage of viable cells observed at $24 \mathrm{~h}$ with SAC and AGE treatment was maintained at $48 \mathrm{~h}$. It suggests that both compounds retain cell viability along time. The marked decrease of cell viability in vehicle treated cells ( $48 \mathrm{~h}$ compared to $24 \mathrm{~h}$ ) evidences this protective effect. SAC and AGE did not show a dose dependent effect, probably because the recovery of cell function at $5 \mathrm{mM} \mathrm{SAC}$ or $0.5 \% \mathrm{AGE}$ is the maximum recovery we could obtain for the $1.0 \mathrm{mM} \mathrm{CoCl}_{2}$-induced damage in PC12 cells. We suggest that protective mechanisms of both SAC and AGE may depend on the severity of the stimulus, which could trigger different molecular responses, such as the differences observed in HIF-1 $\alpha$ activity at both $\mathrm{CoCl}_{2}$ concentrations (Fig. 2).
The decrease in Sub-G $G_{0}$ values after treatment with SAC or AGE confirmed this protection. This technique allows quantification of the number of cells through DNA fragmentation. To differentiate early apoptotic cells, we performed flow cytometry with Annexin V/7AAD double staining. Sub- $G_{0}$ results were corroborated by the Annexin V-7AAD assay, and a significant preservation of the number of live cells was observed after AGE or SAC treatment. Although this assay does not distinguish between late apoptotic and necrotic cells since both of them are Annexin and 7-AAD positive (Q2: Annexin +/7-AAD +), previous characterization of $\mathrm{CoCl}_{2}$-induced cell death strongly suggest that the cells in Q2 are mainly apoptotic. In addition, we used another well-known apoptotic inducer in PC12 cells (Additional file 1: Figure S1). As expected, and in accordance to $\mathrm{CoCl}_{2}$ effect, cells are mainly distributed in Q2 and Q3 in response to staurosporine $200 \mathrm{nM}$. Since we strictly cannot differentiate necrotic cells, we labeled Q2 as late apoptotic and necrotic cells. Observed cell death depended on the $\mathrm{CoCl}_{2}$ concentration and incubation time; furthermore, SAC or AGE decreased the number of cells in early apoptosis as well as in late stages of apoptosis (plus possible necrotic cells).

AGE and SAC attenuated HIF- $1 \alpha$ stabilization and binding to HRE sequences, suggesting a direct effect on the transcriptional activity of HIF-1 $\alpha$. Several reports suggest that ROS induces HIF- $1 \alpha$ protein stabilization $[31,32]$. It has been reported that ROS activates the HIF-1 $\alpha$ promoter via a NFKB site, suggesting that these factors are important in disorders that show increased levels of ROS [33]; in addition, the effects of ROS on HIF- $1 \alpha$ can also be affected by the degree of hypoxia, the form and intracellular location of ROS produced during hypoxia and the molecular microenvironment of the cell [34]. Under hypoxic conditions, mitochondrial complex III may produce ROS, and the presence of high ROS concentrations generated from the mitochondria has been shown to stabilize HIF-1 $\alpha$ [35-38]. However, it has been suggested that mitochondrial-independent mechanisms are primarily responsible for $\mathrm{CoCl}_{2}$-induced ROS generation and the activation of HIF- $1 \alpha[10,11]$. However, the generation of ROS could also be due to NADPH oxidases in the cytosol. Regardless, ROS influence HIF- $1 \alpha$ activity. We observed that a decrease in activated HIF-1 $\alpha$ correlates with a decrease in $\mathrm{CoCl}_{2}$-induced ROS after SAC or AGE treatment. There are several hypotheses that can explain the stabilization of HIF-1 $\alpha$ expression by ROS: 1) $\mathrm{Fe}^{2+}$ oxidation by $\mathrm{H}_{2} \mathrm{O}_{2}$ affects PHDs activity; 2) prevention of $\mathrm{Fe}^{3+}$ reduction by ascorbate; 3) prevention of ascorbate from binding to PHDs; 4) or a ROS-induced change in $\mathrm{O}_{2}$ availability that affects HIF binding to PHDs [34]. The concentrations of $\mathrm{CoCl}_{2}$ used in our study have 


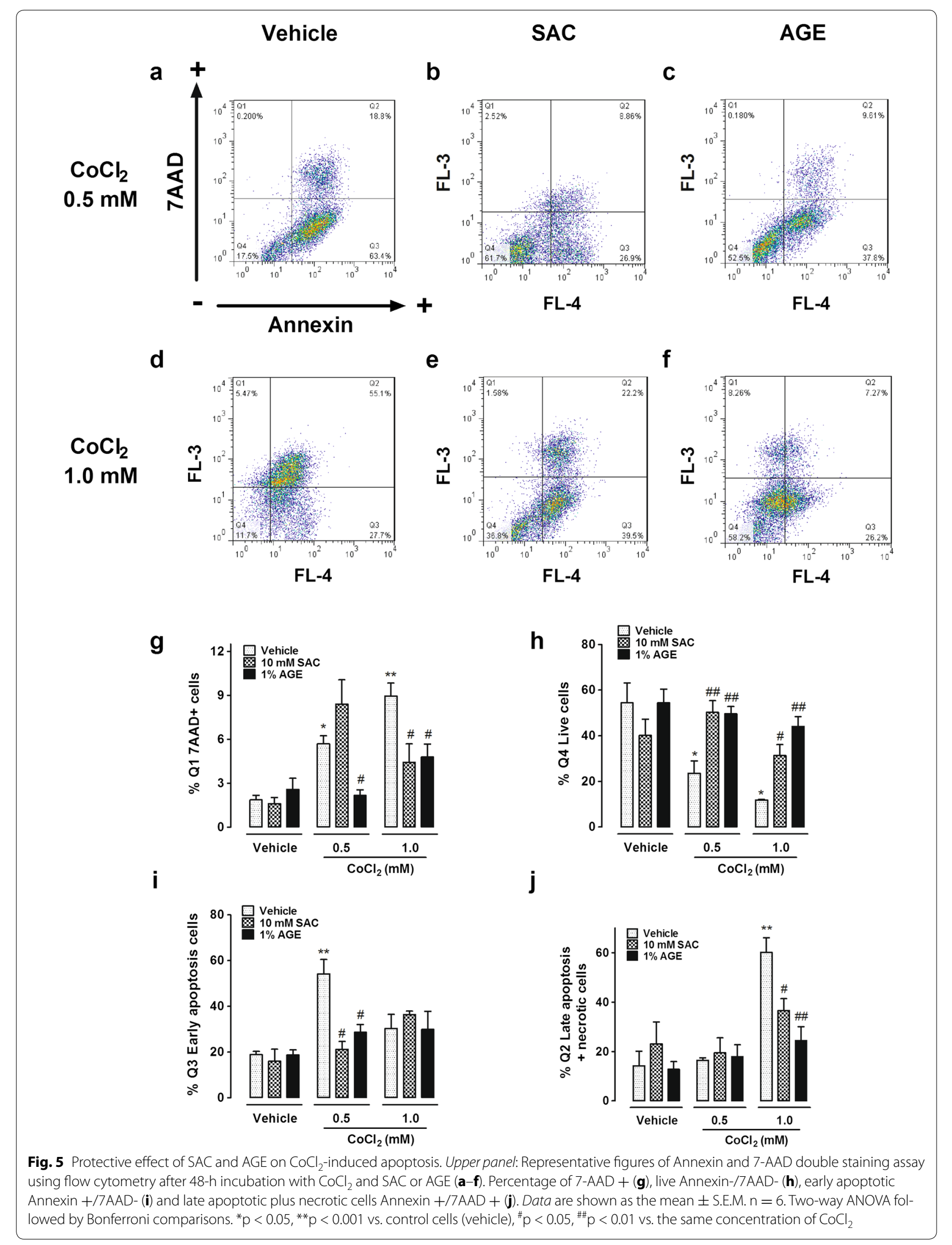



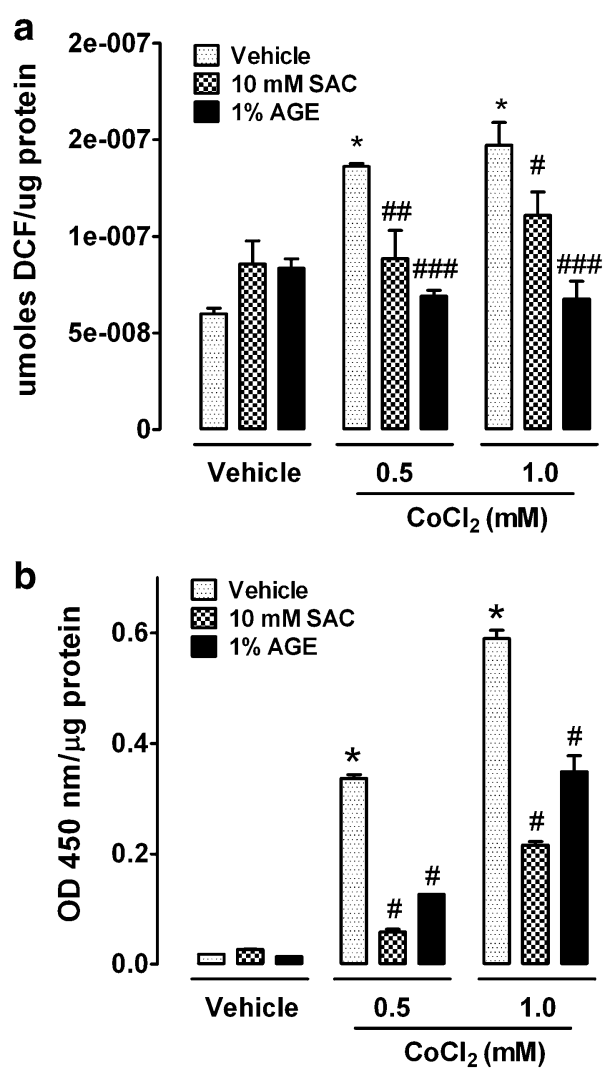

Fig. $6 \mathrm{SAC}$ and $\mathrm{AGE}$ attenuates $\mathrm{CoCl}_{2}$-induced overproduction of ROS and HIF-1a stabilization and binding activity. a Cells were incubated with $\mathrm{COCl}_{2}$ and SAC or AGE to determine intracellular ROS levels. Data are shown as the mean \pm S.E.M. $n=6 .{ }^{*} p<0.001$ vs. vehicle. $\# p<0.05,{ }^{\# \#} p<0.01$ and ${ }^{\# \# \#} p<0.001$ vs. the same concentration of $\mathrm{CoCl}_{2}$. b Binding of stabilized HIF-1a to HRE sequences was determined using an ELISA. Data are shown as the mean \pm S.E.M. $n=3$. Two-way ANOVA followed by Bonferroni comparisons. ${ }^{*} p<0.001$ vs. vehicle; ${ }^{\#} p<0.001$ vs. the same concentration of $\mathrm{CoCl}_{2}$

been shown to induce oxidant stress in cells and oxidize intracellular ascorbate [39], confirming that ROS affects HIF- $1 \alpha$ stability.

Thus, SAC and AGE prevent HIF- $1 \alpha$ activation due to their antioxidant nature, which leads to a decrease in apoptotic cell death. The antioxidant effect of SAC and AGE on HIF- $1 \alpha$ activity has not been described to date. A reduction in HIF- $1 \alpha$ levels has also resulted in protection in other models [14, 39-41]. The reduction of cell death by blocking HIF-1 $\alpha$ stabilization may be due to the inability of HIF- $1 \alpha$ to induce the transcription of proapoptotic members of the Bcl2 BH3-only family that induce oxidative death, such as BNIP3, PUMA and NOXA [42-44]. Hence, the prevention of apoptotic cell death by SAC and AGE can be explained by the abrogation of HIFmediated transactivation of BH3-only proteins [42].

In summary, we observed a protective effect of AGE and $\mathrm{SAC}$ on $\mathrm{CoCl}_{2}$ toxicity after $\mathrm{CoCl}_{2}$ exposure. The cell viability was preserved by AGE or SAC co-incubation. Flow cytometry showed that both garlic-derived antioxidants decreased the number of dead cells and a decrease in early and late apoptotic cell death after AGE or SAC treatment, depending on the $\mathrm{CoCl}_{2}$ concentration and incubation time used. Both garlic derivatives decreased HIF- $1 \alpha$ stabilization and nuclear translocation, suggesting that their antioxidant role directly affects the transcriptional activity of HIF- $1 \alpha$ and subsequently blocks the transcription of prodeath HIF- $1 \alpha$ regulated genes.

\section{Conclusions}

HIF modulation is an attractive strategy for the therapeutic intervention of pathological conditions affected by hypoxia and for the study of hypoxic mechanisms; however, fundamental studies are required before testing in clinical trials. We suggest that the use of SAC or AGE is a plausible strategy to minimize the prodeath effects of HIF- $1 \alpha$ and the consequent cell death associated with hypoxia and oxidative stress conditions. However, further research is necessary to elucidate the exact signaling pathways involved. The mechanisms behind apoptosis and its relationship with HIF- $1 \alpha$ activity can be used to translate the full potential of AGE and SAC into a preventive strategy to counteract hypoxic consequences.

\section{Methods}

\section{Materials}

All reagents were analytical grade and commercially available. AGE Kyolic ${ }^{\circledR}$ was obtained from Wakunaga of America Co. (Ltd, Mission Viejo, CA, USA). This garlic extract complies with the specifications established in the US Pharmacopeia/National Formulary [24].

\section{Synthesis of S-allylcysteine (SAC)}

SAC was synthesized by the reaction of L-cysteine with allyl bromide and purified by recrystallization from an ethanol-water solution. The final product was compared with a SAC standard using thin layer chromatography, high performance liquid chromatography, ${ }^{1} \mathrm{H}$ nuclear magnetic resonance (NMR), infra-red and electronic ionization-mass spectroscopy (EI-MS). A detailed procedure for SAC synthesis, purification and identification of the final chemical compound are reported in [26]. The melting point of the SAC standard is $220-222{ }^{\circ} \mathrm{C}$, and the melting point of the SAC used in this study was $218-219^{\circ} \mathrm{C}$. The analysis of the final product by high performance liquid chromatography showed one peak with a retention time of $12.38 \mathrm{~min}$.

\section{Cell culture}

PC12 cells were obtained from the American Type Culture Collection (Rockville, MD, USA). Cells were routinely 
cultured in Dulbecco's modified Eagle's Medium (DMEM) with $7.5 \%$ heat-inactivated horse serum and $7.5 \%$ fetal bovine serum at $37{ }^{\circ} \mathrm{C}$ in a humidified atmosphere of $5 \% \mathrm{CO}_{2} / 95 \%$ air [14]. Cells were seeded at a density of $7.5 \times 10^{4}$ cells $/ \mathrm{cm}^{2}$. For experiments, confluent cultures were maintained in DMEM free of serum.

\section{Experimental design}

Cells were incubated for 24 or $48 \mathrm{~h}$ at $37{ }^{\circ} \mathrm{C}$ in one of the following conditions: vehicle (DMEM free of serum); SAC (5 or $10 \mathrm{mM}$ ); AGE (0.5 or $1.0 \%)$; $\mathrm{CoCl}_{2}(0.5$ or $1.0 \mathrm{mM}$ ); $\mathrm{CoCl}_{2} 0.5 \mathrm{mM}$ plus SAC (5 or $10 \mathrm{mM}$ ); $\mathrm{CoCl}_{2} 1.0 \mathrm{mM}$ plus SAC ( 5 or $10 \mathrm{mM}$ ); $\mathrm{CoCl}_{2} 0.5 \mathrm{mM}$ plus AGE (0.5 or $1.0 \%$ ); or $\mathrm{CoCl}_{2} 1.0 \mathrm{mM}$ plus AGE (0.5 or $1.0 \%$ ). Cells were harvested and used to evaluate HIF-1 $\alpha$ activation, cell viability and Sub- $\mathrm{G}_{0}$ levels using an enzyme-linked immunosorbent assay (ELISA), 3-(4,5-dimethylthiazol2-yl)-2,5-diphenyltetrazolium bromide (MTT) reduction assay and Annexin V/7-aminoactinomycin D (7-AAD) double staining with flow cytometry, respectively. Intracellular ROS levels were determined using 2'7'dichlorofluorescein diacetate (DCFH-DA) in cells incubated for $1 \mathrm{~h}$ under the aforementioned conditions.

\section{Cell viability assay}

Cell viability was assessed using a MTT reduction assay as previously reported [14]. MTT $\left(0.5 \mathrm{mg} \mathrm{ml}^{-1}\right)$ was added to each well, and cells were incubated at $37^{\circ} \mathrm{C}$ for $1.5 \mathrm{~h}$. The formazan blue product was spectroscopically quantified at $570 \mathrm{~nm}$. Data are expressed as the percentage of MTT reduction compared to control wells. The data were confirmed by bright field micrographs.

\section{HIF-1a activity assay}

Cell nuclear fractions were obtained using a NE-PER ${ }^{\circledR}$ Nuclear and Cytoplasmic Extraction Reagents kit, (PIERCE, Thermo Scientific, Rockford, IL, USA), and the protein concentration was determined. Stabilized HIF- $1 \alpha$ bound to the HRE sequence was determined using an ELISA-HIF-1 $\alpha$ activity Transcription Factor Assay Kit (Cayman Chemical Co. Ann Arbor, MI, USA) according to the manufacturer's instructions. The results are expressed as OD $450 \mathrm{~nm} / \mu \mathrm{g}$ protein.

\section{Flow cytometry}

Based on the methods of [45], FACS analysis was used to determine the Sub- $\mathrm{G}_{0}$ peak and the level of apoptosis after staining with propidium iodide (PI) or Annexin $\mathrm{V}$ and 7-AAD, respectively. A total of 10,000 events were evaluated, and data were collected on a FACSCalibur instrument (BD Biosciences, Franklin Lakes, NJ, USA). Data analysis was conducted using Cell QuestPro and Flow Jover 7.6.1 software.

\section{Reactive oxygen species measurement}

Intracellular ROS levels were determined by the oxidative conversion of DCFH-DA to DCF. PC12 cells were cultured in 6-well plates. Cells were incubated for $1 \mathrm{~h}$ using the previously described treatment conditions. Cells were washed twice with PBS, and the $10 \mu \mathrm{M}$ DCFH-DA in serum-free medium was added. Next, cells were incubated for $30 \mathrm{~min}$ at $37^{\circ} \mathrm{C}$ in the dark. Cells were washed twice with PBS, lysed in phosphate buffer $(50 \mathrm{mM} \mathrm{pH}$ 7.4, $1 \% \mathrm{v} / \mathrm{v}$ Triton X-100) and centrifuged for $20 \mathrm{~min}$ at $12,000 \mathrm{~g}$. The fluorescence intensity was determined at excitation/emission wavelengths of $488 \mathrm{~nm} / 515 \mathrm{~nm}$. Micromoles of DCF were determined with a DCF calibration curve.

\section{Statistical analyses}

Data are expressed as the mean \pm S.E.M. and were analyzed using Prism 5 software (GraphPad, San Diego, CA, USA), applying analysis of variance (ANOVA) followed by the Bonferroni Multiple Comparison test or Dunnett's test, as appropriate. A value of $\mathrm{p}<0.05$ was considered significant.

\section{Additional file}

Additional file 1: Figure S1. Positive control for PC12 cells apoptosis induced by staurosporine. PC12 cells were incubated in the same conditions described in Methods. Representative figure of flow cytometry for Annexin and PI double staining assay after $24 \mathrm{~h}$ incubation with staurosporine $200 \mathrm{nM}$ (a). Graph shows results from three different experiments. Q1, PI single positive cells; Q2, Annexin +/IP + (late apoptotic and necrotic cells); Q3, Annexin +//P- early apoptotic cells; Q4, Annexin-/IPlive cells (b). Data are shown as the mean \pm S.E.M. $n=3$.

\section{Abbreviations}

DCFH-DA: 2,7'dichlorofluorescein diacetate; DCF: 2', 7'dichlorofluorescein; MTT: 3-(4,5-dimethylthiazol-2-yl)-2,5-diphenyltetrazolium bromide; 7-AAD: 7-Aminoactinomycin D; AGE: aged garlic extract; ANOVA: analysis of variance; $\mathrm{CoCl}_{2}$ : cobalt chloride; DMEM: Dulbecco's modified eagle's medium; ELISA: enzymelinked immunosorbent assay; $\mathrm{H}_{2} \mathrm{O}_{2}$ : hydrogen peroxide; $\mathrm{HIF-1}$ : hypoxia inducible factor; HRE: hypoxia response elements; $\mathrm{O}_{2}$ : oxygen; PI: propidium iodide; ROS: reactive oxygen species; SAC: S-allylcysteine.

\section{Authors' contributions}

M.O-I.; J.M-S., M.Z-M., B.P.; R.M-M. and M.E.C-C. Conducted research: Experiments and data collection. M.O-I. Analyzed data and performed statistical analysis. M.O-I.; E V-C; J. P-C and P. M.: Provided essential reagents and material. E V-C; P. M; J. P-C and M.E.C-C: Study oversight and development of overall research., M.E.C-C: Designed research: Project conception; development of overall research plan. Analyzed data and wrote paper. All authors read and approved the final manuscript.

\section{Author details}

1 Laboratorio de Neurobiología Molecular y Celular, Instituto Nacional de Neurología y Neurocirugía Manuel Velasco Suárez, Delegación Tlalpan, 14269 Mexico, D.F., Mexico. ${ }^{2}$ Laboratorio de Patología Vascular Cerebral, Instituto Nacional de Neurología y Neurocirugía Manuel Velasco Suárez, Av. Insurgentes Sur \# 3877, Colonia La Fama, Delegación Tlalpan, 14269 Mexico D.F., Mexico. ${ }^{3}$ Laboratorio de Neuroinmunología y Neuro-oncología, Instituto Nacional de Neurología y Neurocirugía Manuel Velasco Suárez, Delegación Tlalpan, 14269 Mexico D.F., Mexico. ${ }^{4}$ Departamento de Ciencias Naturales, 
CNI, Universidad Autónoma Metropolitana Cuajimalpa, Av. Vasco de Quiroga 4871: Col. Santa Fe, Delegación Cuajimalpa de Morelos, 05348 Mexico D.F., Mexico. ${ }^{5}$ Departamento de Biología, Facultad de Química, Universidad Nacional Autónoma de México, Ciudad Universitaria, 04510 Mexico D.F., Mexico.

\section{Acknowledgements}

This work was supported in part by PAPIIT IN2i0713 and CONACYT 220046, 168356, 129838, 252008 and ICYTDF/229/2012. Martín E. Zavala-Medina received a scholarship from the Armstrong Foundation in México. Jorge Muñoz-Sánchez acknowledges the scholarship and financial support provided by the National Council of Science and Technology (CONACYT) and the National Autonomous University of Mexico (UNAM).

\section{Competing interests}

All authors declare that they have no competing interest.

Received: 9 September 2015 Accepted: 14 January 2016

Published online: 01 February 2016

\section{References}

1. Brahimi-Horn MC, Chiche J, Pouyssegur J. Hypoxia signalling controls metabolic demand. Curr Opin Cell Biol. 2007;19:223-9.

2. Lendahl U, Lee KL, Yang H, Poellinger L. Generating specificity and diversity in the transcriptional response to hypoxia. Nat Rev Genet. 2009;10:821-32

3. Semenza GL. HIF-1 and mechanisms of hypoxia sensing. Curr Opin Cell Biol. 2001;13:167-71.

4. Rocha S. Gene regulation under low oxygen: holding your breath for transcription. Trends Biochem Sci. 2007;32:389-97.

5. Semenza GL. Oxygen sensing, hypoxia-inducible factors, and disease pathophysiology. Annu Rev Pathol. 2014;9:47-71.

6. Caltana L, Merelli A, Lazarowski A, Brusco A. Neuronal and glial alterations due to focal cortical hypoxia induced by direct cobalt chloride ( $\mathrm{CoCl} 2)$ brain injection. Neurotox Res. 2009:15:348-58.

7. Kalpana S, Dhananjay S, Anju B, Lilly G. Sai Ram M. Cobalt chloride attenuates hypobaric hypoxia induced vascular leakage in rat brain: molecular mechanisms of action of cobalt chloride. Toxicol Appl Pharmacol. 2008;231:354-63.

8. Lan A, Liao X, Mo L, Yang C, Yang Z, Wang X, Hu F, Chen P, Feng J, Zheng $D$, Xiao L. Hydrogen sulfide protects against chemical hypoxia-induced injury by inhibiting ROS-activated ERK1/2 and P38MAPK signaling pathways in PC12 Cells. PLoS One. 2011;6:e25921.

9. Lan AP, Xiao LC, Yang ZL, Yang CT, Wang XY, Chen PX, Gu MF, Feng JQ. Interaction between ROS and p38MAPK contributes to chemical hypoxiainduced injuries in PC12 cells. Mol Med Report. 2012;5:250-5.

10. Chandel NS, Maltepe E, Goldwasser E, Mathieu CE, Simon MC, Schumacker PT. Mitochondrial reactive oxygen species trigger hypoxiainduced transcription. Proc Natl Acad Sci. 1998;95:11715-20.

11. Hamanaka RB, Chandel NS. Mitochondrial reactive oxygen species regulate hypoxic signaling. Curr Opin Cell Biol. 2009;21:894-9.

12. Jung JY, Kim WJ. Involvement of mitochondrial- and Fas-mediated dual mechanism in $\mathrm{CoCl}_{2}$-induced apoptosis of rat PC12 cells. Neurosci Lett. 2004;371:85-90.

13. Zou W, Zeng J, Zhuo M, Xu W, Sun L, Wang J, Liu X. Involvement of caspase-3 and p38 mitogen-activated protein kinase in cobalt chorideinduced apoptosis in PC12 cells. J Neurosci Res. 2002;67:837-43.

14. Guo LX, Liu JH, Xia ZN. Geniposide inhibits $\mathrm{CoCl}_{2}$-induced PC12 cells death via the mitochondrial pathway. Chin Med J (Engl). 2009;122:2886-92.

15. Wang G, Hazra TK, Mitra S, Lee HM, Englander EW. DNA damage and a hypoxic response are induced by $\mathrm{CoCl}_{2}$ in rat neuronal PC12 cells. Nucleic Acids Res. 2000;28:2135-40.

16. Jung JY, Roh KH, Jeong YJ, Kim SH, Lee EJ, Kim MS, Oh WM, Oh HK, Kim WJ. Estradiol protects PC12 cells against $\mathrm{CoCl} 2$-induced apoptosis. Brain Res Bull. 2008:76:579-85.

17. Amagase H, Petesch BL, Matsuura H, Kasuga S, Itakura Y. Intake of garlic and its bioactive components. J Nutr. 2001;131:955S-62S.
18. Lawson LD. The composition and chemistry of garlic cloves and processed garlic. In: Koch HP, Lawson LD, editors. The Science and Therapeutic Application of Allium sativum L. and Related Species. Baltimore: Williams and Wilkins; 1996. p. 37-107.

19. Colín-González AL, Santana RA, Silva-Islas CA, Chánez-Cárdenas ME, Santamaria A, Maldonado PD. The antioxidant mechanisms underlying the effects of aged garlic extract and S-allylcysteine-induced protection. Oxid Med Cell Longev. 2012;2012:907162.

20. Numagami Y, Sato S, Ohnishi ST. Attenuation of rat ischemic brain damage by aged garlic extracts: a possible protecting mechanism as antioxidants. Neurochem Int. 1996;29:135-43.

21. Aguilera P, Chánez-Cárdenas ME, Ortiz-Plata A, León-Aparicio D, Barrera D, Espinoza-Rojo M, Villeda-Hernández J, Sánchez-García A, Maldonado PD. Aged garlic extract delays the appearance of infarct area in a cerebral ischemia model, an effect likely conditioned by the cellular antioxidant systems. Phytomedicine. 2010;17:241-7.

22. Colín-González AL, Ortiz-Plata A, Villeda-Hernández J, Barrera D, MolinaJijón E, Pedraza-Chaverrí J, Maldonado PD. Aged garlic extract attenuates cerebral damage and cyclooxygenase-2 induction after ischemia and reperfusion in rats. Plant Foods Hum Nutr. 2011;66:348-54.

23. Maldonado PD, Limón D, Galván-Arzate S, Santamaria A. Pedraza-Chaverrí J Medicinal properties of garlic: importance of its antioxidant activity. In: Pãcurar M, Krejci G, editors. Garlic Consumption and Health. New York: Nova Science Publisher Inc; 2009. p. 61-116.

24. Aged Garlic Extract, 2006. Research excerpts from peer reviewed scientific journals and scientific meetings. Wakunaga of America Co. Ltd., Mission Viejo, p. 1.

25. Medina-Campos ON, Barrera D, Segoviano-Murillo S, Rocha D, Maldonado PD, Mendoza-Patiño N, Pedraza-Chaverri J. S-allylcysteine scavenges singlet oxygen and hypochlorous acid and protects LLC-PK(1) cells of potassium dichromate-induced toxicity. Food Chem Toxicol. 2007:45:2030-9.

26. Maldonado PD, Alvarez-Idaboy JR, Aguilar-González A, Lira-Rocha A, Jung-Cook H, Medina-Campos ON, Pedraza-Chaverri J, Galano A. Role of allyl group in the hydroxyl and peroxyl radical scavenging activity of S-allylcysteine. J Phys Chem B. 2011;115:13408-17.

27. Ho SE, Ide N, Lau BH. S-allyl cysteine reduces oxidant load in cells involved in the atherogenic process. Phytomedicine. 2001;8:39-46.

28. Kosuge Y, Koen Y, Ishige K, Minami K, Urasawa H, Saito H, Ito Y. S-allyl-Lcysteine selectively protects cultured rat hippocampal neurons from amyloid beta-protein and tunicamycin-induced neuronal death. Neurosci. 2003;122:885-95.

29. Velasco-Velázquez MA, Maldonado PD, Barrera D, Torres V, ZentellaDehesa A, Pedraza-Chaverrí J. Aged garlic extract induces proliferation and ameliorates gentamicin-induced toxicity in LLC-PK1 cells. Phytother Res. 2006;20:76-8.

30. Berginc K, Trontelj J, Kristl A. The influence of aged garlic extract on the uptake of saquinavir and darunavir into HepG2 cells and rat liver slices. Drug Metab Pharmacokinet. 2010;25:307-13.

31. Jusman SW, Halim A, Wanandi SI, Sadikin M. Expression of hypoxiainducible factor-1alpha (HIF-1alpha) related to oxidative stress in liver of rat-induced by systemic chronic normobaric hypoxia. Acta Med Indones. 2010:42:17-23.

32. Deshmane SL, Mukerjee R, Fan S, Del Valle L, Michiels C, Sweet T, Rom I, Khalili K, Rappaport J, et al. Activation of the oxidative stress pathway by HIV-1 Vpr leads to induction of hypoxia-inducible factor 1alpha expression. J Biol Chem. 2009;284:11364-73.

33. Bonello S, Zähringer C, BelAiba RS, Djordjevic T, Hess J, Michiels C, Kietzmann T, Görlach A. Reactive oxygen species activate the HIF-1alpha promoter via a functional NFkappaB site. Arterioscler Thromb Vasc Biol. 2007;27:755-61.

34. Qutub AA, Popel AS. Reactive oxygen species regulate hypoxia-inducible factor 1alpha differentially in cancer and ischemia. Mol Cell Biol. 2008:28:5106-19.

35. Bell EL, Chandel NS. Mitochondrial oxygen sensing: regulation of hypoxiainducible factor by mitochondrial generated reactive oxygen species. Essays Biochem. 2007:43:17-27.

36. Bell EL, Klimova TA, Eisenbart J, Moraes CT, Murphy MP, Budinger GRS, et al. The Q(o) site of the mitochondrial complex III is required for the transduction of hypoxic signaling via reactive oxygen species production. J Cell Biol. 2007:177:1029-36. 
37. Brunelle JK, Bell EL, Quesada NM, Vercauteren K, Tiranti V, Zeviani M, Scarpulla RC, Chandel NS. Oxygen sensing requires mitochondrial ROS but not oxidative phosphorylation. Cell Metab. 2005;1:409-14.

38. Chandel NS, McClintock DS, Feliciano CE, Wood TM, Melendez JA, Rodriguez AM, Schumacker PT. Reactive oxygen species generated at mitochondrial complex III stabilize hypoxia-inducible factor-1alpha during hypoxia: a mechanism of $\mathrm{O}_{2}$ sensing. J Biol Chem. 2000;275:25130-8.

39. Qiao H, Li L, Qu ZC, May JM. Cobalt-induced oxidant stress in cultured endothelial cells: prevention by ascorbate in relation to HIF-1alpha. BioFactors. 2009;35:306-13.

40. Han DD, Wang Y, Zhang XH, Liu JR, Wang HL. Fluoxetine protects against monocrotaline-induced pulmonary arterial remodeling by inhibition of hypoxia-inducible factor-1 $a$ and vascular endothelial growth factor. Can J Physiol Pharmacol. 2012;90:445-54.

41. Agrawal M, Kumar V, Kashyap MP, Khanna VK, Randhawa GS, Pant AB. Ischemic insult induced apoptotic changes in PC12 cells: protection by trans resveratrol. Eur J Pharmacol. 2011;666:5-11.
42. Aminova LR, Siddiq A, Ratan RR. Antioxidants, HIF prolyl hydroxylase inhibitors or short interfering RNAs to BNIP3 or PUMA, can prevent prodeath effects of the transcriptional activator, HIF-1alpha, in a mouse hippocampal neuronal line. Antioxid Redox Signal. 2008;10:1989-98.

43. Bruick RK. Expression of the gene encoding the proapoptotic Nip3 protein is induced by hypoxia. Proc Natl Acad Sci U S A. 2000;97:9082-7.

44. Kim JY, Ahn HJ, Ryu JH, Suk K, Park JH. BH3-only protein Noxa is a mediator of hypoxic cell death induced by hypoxia-inducible factor 1a. J Exp Med. 2004;199:113-24.

45. Orozco-Morales M, Sánchez-García FJ, Guevara-Salazar P, Arrieta O, Hernández-Pedro NY, Sánchez-García A, Perez-Madrigal R, Rangel-López E, Pineda B, Sotelo J. Adjuvant immunotherapy of C 6 glioma in rats with pertussis toxin. J Cancer Res Clin Oncol. 2012;138:23-33.

\section{Submit your next manuscript to BioMed Central and we will help you at every step:}

- We accept pre-submission inquiries

- Our selector tool helps you to find the most relevant journal

- We provide round the clock customer support

- Convenient online submission

- Thorough peer review

- Inclusion in PubMed and all major indexing services

- Maximum visibility for your research

Submit your manuscript at www.biomedcentral.com/submit
(OioMed Central 